\title{
A Summary of NASA and USAF Hypergolic Propellant Related Spills and Fires
}

\author{
B. Nufer \\ System Engineer \\ NASA Kennedy Space Center, Engineering Directorate, Fluids Division, Hypergolic and Hydraulic Systems Branch \\ Mail Stop: NE-F5 \\ Kennedy Space Center, FL 32899
}

\begin{abstract}
Several unintentional hypergolic fluid related spills, fires, and explosions from the Apollo Program, the Space Shuttle Program, the Titan Program, and a few others have occurred over the past several decades. Spill sites include the following government facilities: Kennedy Space Center (KSC), Johnson Space Center (JSC), White Sands Test Facility (WSTF), Vandenberg Air Force Base (VAFB), Cape Canaveral Air Force Station (CCAFS), Edwards Air Force Base (EAFB), Little Rock AFB, and McConnell AFB. Until now, the only method of capturing the lessons learned from these incidents has been "word of mouth" or by studying each individual incident report. Through studying several dozen of these incidents, certain root cause themes are apparent. Scrutinizing these themes could prove to be highly beneficial to future hypergolic system test, checkout, and operational use.
\end{abstract}

\section{Introduction}

Hypergolic fluids are toxic liquids that react spontaneously and violently when they contact each other. These fluids are used in many different rocket and aircraft systems for propulsion and hydraulic power including: orbiting satellites, manned spacecraft, military aircraft, and deep space probes. Hypergolic fuels include hydrazine $\left(\mathrm{N}_{2} \mathrm{H}_{4}\right)$ and its derivatives including: monomethylhydrazine (MMH), unsymmetrical di-methylhydrazine (UDMH), and Aerozine 50 (A-50), which is an equal mixture of $\mathrm{N}_{2} \mathrm{H}_{4}$ and UDMH. The oxidizer used with these fuels is usually nitrogen tetroxide $\left(\mathrm{N}_{2} \mathrm{O}_{4}\right)$, also known as dinitrogen tetroxide or $\mathrm{NTO}$, and various blends of $\mathrm{N}_{2} \mathrm{O}_{4}$ with nitric oxide (NO).

Several documented, unintentional hypergolic fluid spills and fires related to the Apollo Program, the Space Shuttle Program, and several other programs from approximately 1968 through the spring of 2009 have been studied for the primary purpose of extracting the lessons learned. Spill sites include Kennedy Space Center (KSC), Johnson Space Center (JSC), White Sands Test Facility (WSTF), Vandenberg Air Force Base (VAFB), Cape Canaveral Air Force Station (CCAFS), Edwards Air Force Base (EAFB), Little Rock AFB, and McConnell AFB.

\section{A. Properties of Nitrogen Tetroxide $\left(\mathrm{N}_{2} \mathrm{O}_{4}\right)$}

Nitrogen tetroxide is a strong oxidizing agent that is used with the hydrazine family of fuels for rocket propulsion in the vacuum of space. It was accepted as the rocket propellant oxidizer of choice in the early 1950's by the U.S.S.R. and the United States. $\mathrm{N}_{2} \mathrm{O}_{4}$ itself is nonflammable, non-explosive, and does not exothermically decompose; however, when added to a fire it will increase the intensity of combustion and burning rate by providing an additional oxygen source to the air. ${ }^{1} \mathrm{~N}_{2} \mathrm{O}_{4}$ is highly corrosive and extremely toxic. $\mathrm{N}_{2} \mathrm{O}_{4}$ is a liquid in equilibrium with nitrogen dioxide $\left(\mathrm{NO}_{2}\right)$ vapor: $\mathrm{N}_{2} \mathrm{O}_{4}$ (liquid) $\leftrightarrow 2 \mathrm{NO}_{2}$ (vapor). This equilibrium favors the vapor with increasing temperature and/or decreasing pressure. This is reversible when conditions are opposite. $\mathrm{N}_{2} \mathrm{O}_{4}$ is available in various "grades" ranging from pure $\mathrm{N}_{2} \mathrm{O}_{4}$ to $25 \%$ NO.

When $\mathrm{N}_{2} \mathrm{O}_{4}$ liquid or $\mathrm{NO}_{2}$ vapor come in contact with skin, eyes, or the respiratory system, the oxides of nitrogen react with water to produce nitric acid $\left(\mathrm{HNO}_{3}\right)$ and nitrous acid (HONO) that typically destroy tissue. Together, these compounds oxidize the moist and flexible inner tissue of the alveoli sacs within the lungs when inhaled which can lead to build-up of fluid (edema) and in extreme cases, death. In non-mortal exposure cases, tissue may heal

\footnotetext{
1 "Fire, Explosion, Compatibility, and Safety Hazards of Nitrogen Tetroxide." American Institute of Aeronautics and Astronautics Special Project Report. AIAA SP-086-2001. 2001.
}

1

American Institute of Aeronautics and Astronautics 
with scarring (in the location where the tissue was significantly exposed), leading to destruction of the small airways and air sacs. Survivors may have varying degrees of permanent restrictive lung disease with pulmonary fibrosis. ${ }^{2}$

$\mathrm{N}_{2} \mathrm{O}_{4}$ and $\mathrm{NO}_{2}$ also have several other unique properties. $\mathrm{N}_{2} \mathrm{O}_{4}\left(\mathrm{NO}_{2}\right)$ vapors are approximately three times heavier than air and liquid $\mathrm{N}_{2} \mathrm{O}_{4}$ evaporates about five times faster than water at room temperature.' The vapors of MON-3 are normally reddish-brown in color, which is caused by rapid vaporization of $\mathrm{NO}_{2}$. Liquid $\mathrm{N}_{2} \mathrm{O}_{4}$ and its vapors will explode on contact with hydrazine fuels, amines, and alcohol. Ignition may also occur when $\mathrm{N}_{2} \mathrm{O}_{4}$ comes into contact with wood, paper, hydrocarbon fuels, and some adhesives. A mixture of $\mathrm{N}_{2} \mathrm{O}_{4}$ and halogenated solvents: carbon tetrachloride, trichloroethylene, perchloroethylene, etc., may produce a violent explosion. ${ }^{1} \mathrm{MON}-3 \mathrm{~N}_{2} \mathrm{O}_{4}$ (the most commonly used $\mathrm{N}_{2} \mathrm{O}_{4}$ ) has the following properties: ${ }^{1,3,4,5}$

\begin{tabular}{|c|c|}
\hline 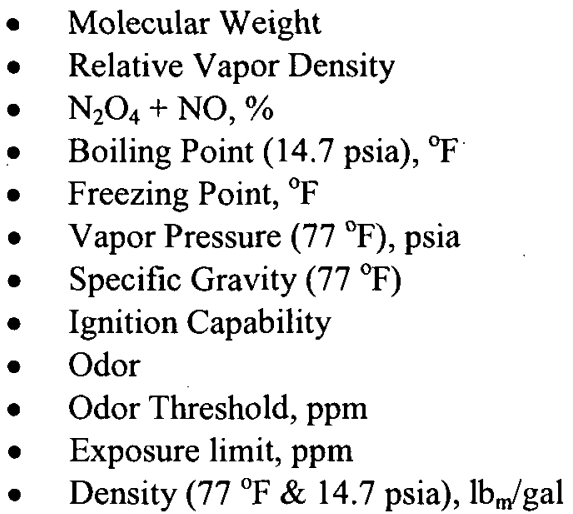 & $\begin{array}{l}92.016 \\
1.58 \\
99.5 \\
70.1 \\
11.8 \\
17.4 \\
1.423 \\
\text { Not flammable } \\
\text { Bleach-like } \\
1 \text { to } 3 \\
3.0 \text { (exposure limit for NASA hardware processing) } \\
11.96\end{array}$ \\
\hline
\end{tabular}

\section{B. Properties of Hydrazine $\left(\mathrm{N}_{2} \mathrm{H}_{4}\right)$ and Monomethylhydrazine (MMH)}

Monopropellant grade hydrazine $\left(\mathrm{N}_{2} \mathrm{H}_{4}\right)$ is the fuel used in the Auxiliary Power Units (APU) on the Space Shuttle Orbiters and the Hydraulic Power Units (HPU) on the Space Shuttle Solid Rocket Boosters (SRBs) to generate high pressure gas for hydraulic power of the orbiter's aero surfaces and the SRB's thrust vector control system. $\mathrm{N}_{2} \mathrm{H}_{4}$ is also used on many spacecraft for monopropellant rocket propulsion systems (on the order of tenths to hundreds of pounds of thrust per rocket engine). To produce thrust, monopropellant rockets utilize a metal-based agent to catalytically decompose the $\mathrm{N}_{2} \mathrm{H}_{4}$ into ammonia, nitrogen, and hydrogen. Propellant grade hydrazine contains about $98.5 \%$ pure $\mathrm{N}_{2} \mathrm{H}_{4}$ with the remaining $1.5 \%$ being primarily water. Aerozine 50 (along with $\mathrm{N}_{2} \mathrm{O}_{4}$ ) was used for the first and second stages of the Titan II Intercontinental Ballistic Missile (ICBM) and Titan space launch vehicles including the 23G (a variant of the Titan II used for launching medium-sized spacecraft), IIIB, IIIC, and IV. The Titan II, IIIB, IIIC, and IV rockets used the largest quantities of hypergolic propellants per launch in the history of the United States rocket fleet (for the first stage approximately 13,000 gallons of $\mathrm{N}_{2} \mathrm{O}_{4}$ and 11,000 gallons of A50 were used along with 3,100 gallons of $\mathrm{N}_{2} \mathrm{O}_{4}$ and 1,700 gallons of $\mathrm{A}-50$ for the second stage).

The Occupational Safety and Health Administration (OSHA) classify $\mathrm{N}_{2} \mathrm{H}_{4}$ and its derivatives as a possible carcinogen. ${ }^{4}$ When hydrazine and its derivatives come into contact with tissue, the exposed person will usually suffer from chemical burns unless the liquid is quickly rinsed off the skin using water. $\mathrm{N}_{2} \mathrm{H}_{4}$ and its derivatives are extremely toxic, highly flammable, and highly corrosive. "Hydrazines and their vapors explode on contact with strong oxidizers, such as $\mathrm{N}_{2} \mathrm{O}_{4}$, hydrogen peroxide, fluorine, and halogen fluorides. Additionally, they react on contact with metallic oxides, such as iron, copper, lead, manganese, and molybdenum to produce fire or explosion.",

\footnotetext{
${ }^{2}$ Myers, Jeffrey, M.D. "RE: Hyper Spills \& Accidents Lessons Learned Report - Toxicology of $\mathrm{NO}_{2}$ Inhalation." Email to Jeffrey Myers and Frank Golan. August 72008.

${ }^{3}$ Hall, George F., Raymond Lake, John H. Storm, and Ross J. Utt. "Fire Protection Research and Development Requirements Analysis for USAF Space Systems and Ground Support Facilities Volume I - Fire Protection Operational Requirements Analysis." Flight Dynamics Directorate Wright Laboratory Air Force Materiel Command, Tyndall Air Force Base, FL. WL-TR-96-3010. April, 1995.

${ }^{4}$ Rathgeber, Kurt A., Bruce Havenor, and Steven D. Hornung Ph.D. "Hypergol Systems: Design, Buildup, and Operation." NSTC Course 055. January 6, 2006.

${ }^{5}$ United States. Dept. of Health, Education, and Welfare (DHEW), Public Health Service, Center for Disease Control, National Institute for Occupational Safety and Health (NIOSH). "Occupational Exposure to Hydrazines." NIOSH Criteria for a Recommended Standard. U.S. DHEW (NIOSH) Publication No. 78-172. June 1978.
} 
Hydrazine fires produce little to no smoke or colorful flames. $\mathrm{N}_{2} \mathrm{H}_{4}$ has a tendency to react exothermically with or without an oxidizer present (the reaction increases the temperature thus increasing the reaction rate; this is also known as a thermal runaway reaction). Another way to describe a hydrazine thermal runaway reaction is "...the rate of heat generation by the reaction exceeds the rate of heat removal from the system." ${ }^{, 6}$ This process is directly related to the auto-ignition temperature, which decreases as pressure increases. The exothermic reaction can end in an explosion if one or more of the following conditions are met within the system containing the hydrazine: the reacting system is confined to a rigid volume; the reacting system is adiabatic or nearly adiabatic; the reaction rate increases with temperature; or if the hydrazine is subjected to rapid over-pressurization through "water hammer."7 The following are properties of $\mathrm{N}_{2} \mathrm{H}_{4}{ }^{4,5,8}$

- Molecular Weight

- Boiling Point (14.7 psia), ${ }^{\circ} \mathrm{F}$

- Freezing Point, ${ }^{\circ} \mathrm{F}$

- Vapor Pressure $\left(77^{\circ} \mathrm{F}\right)$, psia

- Ignition Capability

- Auto-ignites in Air, ${ }^{\circ} \mathrm{F}$

- Ratio of Specific Heat (gas)

- Odor

- Odor Threshold, ppm

- Exposure Limit, ppm

- Density ( $\left.77^{\circ} \mathrm{F} \& 14.7 \mathrm{psia}\right), \mathrm{lb}_{\mathrm{m}} / \mathrm{gal}$
32.045

237.6

34.75

0.96

4.7 to $100 \%$ by volume in air

437 (increases with decreasing pressure)

1.19

Ammonia; fishy

2 to 3

0.01 (exposure limit for NASA hardware processing) 8.38

Monomethylhydrazine is the fuel used in the Orbital Maneuvering System and Reaction Control System (OMS/RCS) on the Space Shuttle Orbiters. Monomethyl-hydrazine, $\mathrm{N}_{2} \mathrm{H}_{3}\left(\mathrm{CH}_{3}\right)$, is similar to hydrazine, $\mathrm{N}_{2} \mathrm{H}_{4}$, with the exception that it contains a methyl group in its molecule in place of one hydrogen atom. Propellant grade $\mathrm{MMH}$ contains $98 \%$ pure $\mathrm{N}_{2} \mathrm{H}_{3}\left(\mathrm{CH}_{3}\right)$ with the remaining $2 \%$ being primarily water. $\mathrm{MMH}$ is not used for monopropellant rocket propulsion because the carbon formed in its decomposition contaminates the catalyst. It is extremely toxic, highly flammable, and highly corrosive. $\mathrm{MMH}$ has greater compatibility with metals as compared to $\mathrm{N}_{2} \mathrm{O}_{4}$.

MMH may have a slight yellow-orange tinted flame. As with $\mathrm{N}_{2} \mathrm{H}_{4}$, MMH can also react exothermically with or without an oxidizer present, but the reaction rate has been found to be much slower than $\mathrm{N}_{2} \mathrm{H}_{4}$. $\mathrm{MMH}$ vapor has also been found to be much less sensitive to detonation as compared to $\mathrm{N}_{2} \mathrm{H}_{4} \cdot{ }^{6}$ As a result of the molecular differences in comparison to $\mathrm{N}_{2} \mathrm{H}_{4}$, MMH has slightly different properties as shown below:, $3,4,7$

- Molecular Weight

- Boiling Point (14.7 psia), ${ }^{\circ} \mathrm{F}$

- Freezing Point, ${ }^{\circ} \mathrm{F}$

- Vapor Pressure $\left(77^{\circ} \mathrm{F}\right)$, psia

- Ignition Capability

- Auto-ignites in Air, ${ }^{\circ} \mathrm{F}$

- Ratio of Specific Heat (gas)

- Odor

- Odor Threshold, ppm

- Exposure Limit, ppm

- Density ( $\left.77^{\circ} \mathrm{F} \& 14.7 \mathrm{psia}\right), \mathrm{lb}_{\mathrm{m}} / \mathrm{gal}$
46.075

189.5

$-62.5$

3.23

2.5 to $98 \%$ by volume in air

286 to 386 (increases with decreasing pressure)

1.13

Amine; fishy

1 to 3

0.01 (exposure limit for NASA hardware processing)

7.27

The vapor densities of all hydrazines are greater than air and the evaporation rate is approximately the same as water at room temperature. $\mathrm{N}_{2} \mathrm{H}_{4}$ liquid at room temperature and pressure is clear and oily. $\mathrm{N}_{2} \mathrm{H}_{4}$ and $\mathrm{MMH}$ are

\footnotetext{
${ }^{6}$ Benz, F. J. and M. D. Pedley. "A Comparison of the Explosion Hazards of Hydrazine and Methylhydrazine in Aerospace Environments." CPIA-PUB-455, Volume 1, pp 477-488. 1986.

7 "Fire, Explosion, Compatibility, and Safety Hazards of Hypergols - Monomethylhydrazine." American Institute of Aeronautics and Astronautics Special Project Report. AIAA SP-085-1999. 1999.

8 "Fire, Explosion, Compatibility, and Safety Hazards of Hypergols - Hydrazine. American Institute of Aeronautics and Astronautics Special Project Report. AIAA SP-084-1999. 1999.
} 
hygroscopic (they readily absorbs water); therefore, water is widely used as a diluting agent. A liquid mixture of $58 \%$ water and $42 \%$ hydrazine or MMH by weight prevents ignition in an open air environment. A vapor mixture of $65 \%$ water and $35 \%$ hydrazine or MMH is considered nonflammable in air. ${ }^{8}$

\section{Summary of Pertinent Hypergolic Fluid Properties}

NASA follows a strict time weighted average exposure concentration limit for $\mathrm{N}_{2} \mathrm{H}_{4}, \mathrm{MMH}$, and $\mathrm{N}_{2} \mathrm{O}_{4}$ for personnel safety during vehicle and ground support system processing. "NASA Centers shall utilize OSHA PEL's [Permissible Exposure Limit], Threshold Limit Values (TLV) issued by the American Conference of Governmental Industrial Hygienists (ACGIH)..." ${ }^{9}$ From these two organizations, NASA established that the TLV for $\mathrm{N}_{2} \mathrm{H}_{4}$ and MMH would be $0.01 \mathrm{ppm}$ and $3 \mathrm{ppm}$ for $\mathrm{N}_{2} \mathrm{O}_{4}$ for a conventional 8-hour work day and 40-hour work week. The National Institute of Occupational Safety and Health's Recommended Exposure Limit (NIOSH REL) ceiling (120 minute time weighted average) for $\mathrm{N}_{2} \mathrm{O}_{4}$ is $1.0 \mathrm{ppm}$. Several NASA Centers have chosen to use this lower value (1.0 ppm) for their oxidizer system processing for a conventional 8-hour work day and 40-hour work week.

It may seem odd that with all these seemingly negative characteristics (and the large amount of incidents when compared to other commodities), spacecraft designers still choose to use hypergols for propulsion systems. This is primarily due to the fact that hypergols are storable and stable (as long as they are contained properly), have a high specific impulse when used for propulsion, are stable to impact as long as there is no spark, can withstand the extremes of hot and cold which are present in the vacuum of space with fewer controls than cryogenic propellants, and can be frozen and then thawed without detrimental effects to their chemical properties or storage vessels since they contract when frozen. However, care needs to be taken when hypergols are frozen in tubing as this can lead to over-pressurization during thaw (depending on the thaw pattern in the tubing). This is why thermal control of tubing is very important in hypergol systems.

\section{Results and Discussion}

A total of 45 hypergolic related incidents were studied for the purpose of compiling common lessons learned. Table 1 and Appendix B summarize the fuel and oxidizer incidents; however, it should be noted that if the numbers in Table 1 are summed in a particular category, the resulting value does not equal 45 because some of the incidents involve multiple commodities or root causes, for example. Appendix B clarifies this difference between the total studied incidents and the summation of the numbers in Table 1.

As shown in Table 1, the ratio of fuel to oxidizer incidents is approximately one-to-one. Also, the severity (personnel injury or the extent of the hardware damage) was approximately the same when comparing fuel and oxidizer incidents. One key difference between a fuel and an oxidizer incident is that a fuel incident has the potential to become very dangerous quite abruptly as compared to an oxidizer incident because of the potential for fire or explosion. Many of the incidents were directly related to some sort of human error along with the occurrence of the event usually taking place during commodity transfer of commodity or opening of a system. Some examples of human error include ground support equipment (GSE) mis-configurations, incorrect valve cycling, poor design of vehicle or GSE (caused by deficient initial requirements or inadequate acceptance testing), training plans that lack the appropriate content, improper system knowledge, immature or inadequate procedures, and improper system monitoring or situational awareness.

Advance warning (prior to any liquid or vapor release) was available in several of the incidents to the technicians in the vicinity of the spill and/or the engineers that were monitoring from a remote location. The warning indications include off-nominal data (remote or local), off-nominal system characteristics, and/or local changes that occurred without human intervention. Some of these went unnoticed or were ignored during the operation, thus resulting in an incident. There was advance warning in 19 out of 38 total incidents (50\% of the time). This percentage does not include spilled fuel as an advance warning of a fire (5 occurrences). Depending on the local environment, there is a reasonable probability that if hydrazine (or one of its derivatives) is spilled, there will be a fire; therefore, the fuel spill itself could be considered an advance warning of a fuel fire. Roughly $42 \%$ of the documented fuel spills studied resulted in a fire or explosion. It was unable to be determined if there was an advanced warning for two of the incidents; therefore, they were not included in the above percentage along with the mentioned 5 fuel spills.

\footnotetext{
${ }^{9}$ United States. National Aeronautics and Space Administration. "NASA Occupational Health Program Procedures." NPR 1800.1 Revision C. Oct: 6, 2009.
} 
Table 1: Hypergol Spill and Fire Summary.

\begin{tabular}{|c|c|c|c|}
\hline \multicolumn{2}{|c|}{ Oxidizer Incidents: } & \multicolumn{2}{|c|}{ Fuel Incidents: } \\
\hline 23 & Total (16 liquid and 7 vapor) & & Total \\
\hline 3 & Led to a Fire & 8 & Led to a Fire \\
\hline 3 & Led to an Explosion & 2 & Led to an Explosion \\
\hline 8 & Led to Injuries or Death & 7 & Led to Injuries or Death \\
\hline 12 & Led to Hardware Damage & & Led to Hardware Damage \\
\hline \multicolumn{4}{|c|}{10 Oxidizer or Fuel Incidents in Which There was No Hardware Damage or Injuries } \\
\hline
\end{tabular}

\begin{aligned} & \hline Root Causes: \\ & \hline 7 Procedure Adherence/Control (engineer or technician did not follow procedure or protocols were ignored) \\ & 11 Improper Personnel Training (engineers or technicians were untrained or too inexperienced) \\ & 17 Technician or Operator Error (technician and/or engineers making a real-time error) \\ & 24 Improper GSE/Vehicle Design (improper materials, unknown low points, incompatibilities, etc.) \\ & 11 Improper Configuration Management (system configuration and upkeep errors that led to an incident) \\ & \hline\end{aligned}

\begin{aligned} & \hline \multicolumn{1}{l}{ Incident Occurred: } \\ & \hline 18 During Commodity Transfer \\ & 15 During a Component Removal and Replacement Procedure \\ & 41 During a Hypergol Operation (nominal system processing) \\ & 13 During Opened Hyper System \\ & 3 In a Static Hyper System \\ & \hline\end{aligned}

Some common lessons learned deduced from the various root causes of the studied incidents are shown in the following list. If these items were properly addressed prior to the incidents, prevention may have been possible (in hindsight) or the ramifications of the incident could have been reduced.

- Improper configuration control and internal or external human performance shaping factors can lead to a false comfort level

- Vent systems are often neglected and treated as non-hazardous even though they can capture and contain condensed hypergolic liquids (especially in low points)

- Aging support hardware should be routinely inspected to reduce the risk of a failure during critical operations

- Communication breakdown can escalate an incident to a level where injuries occur or hardware is damaged

- Communication protocols should be pre-coordinated prior to an operation

- Improper propulsion system and ground support system designs can destine a system for failure

- Every effort should be made to design out low points in GSE

- Improper training of technicians, engineers, and safety personnel can put lives in danger

- Inadequate knowledge of potential electrostatic discharge hazards while working fuel operations can lead to a fire or explosion

- Knowledge of instrumentation error and/or offsets are very important for system oversight

- Unknown incompatibilities (from lack of training or research) with propellants can cause surprising failures

- If an incident does occur, the system should immediately be placed into a stable configuration; following this, the procedure should be stopped to assess the problem and its possible ramifications

- A heightened amount of situational awareness of technicians and engineers working operations can reduce the risk of an incident and decrease the possibility of injuries or damage if an incident does occur . 
- Improper personal protective equipment, spill protection, and staging of fire extinguishing equipment can result in unnecessary injuries or hardware damage if an incident occurs

- Improper procedural oversight (along with the development of and adherence to the procedure) can be detrimental and quickly lead to an incident

- Improper emergency procedures can increase the risk of injuries or hardware damage

- Improper local cleanliness or housekeeping (for example iron oxide or rust) can result in fires or explosions

- A thorough hypergol system evacuation should be completed (wherever a vacuum is tolerable by the system) prior to the removal or disconnection of any hypergolic propellant fittings

- A pulse purge using nitrogen or helium has proven to be inadequate for the removal of residual propellants

\section{Conclusion}

Some type of human error can be traced to nearly every studied incident as a root cause, whether it be an error in the design phase or an error prior to or during operational use of hardware containing hypergols. Humans are most definitely not perfect and even when the most knowledgeable personnel are intimately involved in the design phase (vehicle or GSE) or during an operation, mistakes can be made and critical items can be overlooked. One can deduce, however, that most incidents happen during some sort of dynamic operation. Hypergols tend to be very stable in a static configuration (as long as the compatibility characteristics have been well addressed).

Hypergolic rocket propellants have proven to be a highly reliable asset in manned and unmanned spaceflight; however, their maintenance on the ground has proven to be relatively difficult. Do the operational risks from possible human errors or hardware failures causing a catastrophic incident outweigh the usefulness of hypergols even though they have been used for the last 50 years of manned and unmanned spaceflight? One would have to say probably not, since hypergols are so widely used in the space industry currently and are being proposed to be used on many vehicles in the future. Therefore, ground operations on hypergol systems have become increasingly scrutinized for possible unknowns, and rightfully so. The data shown in this report are not an example of why we should not be using hypergolic propellants on spacecraft and launch vehicles, but rather illustrates what we can and should do to mitigate possible unforeseen ground operation and/or design problems. 


\section{Appendix A}

$\begin{array}{ll}\text { A-50 } & \text { Aerozine-50 } \\ \text { ACGIH } & \text { American Conference of Governmental Industrial Hygienists } \\ \text { AFB } & \text { Air Force Base } \\ \text { APU } & \text { Auxiliary Power Unit } \\ \text { CCAFS } & \text { Cape Canaveral Air Force Station } \\ \text { DHEW } & \text { Department of Health, Education, \& Welfare } \\ \text { EAFB } & \text { Edwards Air Force base } \\ \text { GSE } & \text { Ground Support Equipment } \\ \text { HMF } & \text { Hypergolic Maintenance Facility (located at KSC) } \\ \text { HNO3 } & \text { Nitric Acid } \\ \text { HONO } & \text { Nitrous Acid } \\ \text { HPU } & \text { Hydraulic Power Unit } \\ \text { ICBM } & \text { Intercontinental Ballistic Missile } \\ \text { JSC } & \text { Johnson Space Center } \\ \text { KSC } & \text { Kennedy Space Center } \\ \text { LC } & \text { Launch Complex } \\ \text { MMH } & \text { Monomethylhydrazine (N }{ }_{2} \mathrm{H}_{3}\left(\mathrm{CH} \mathrm{H}_{3}\right) \text { ) } \\ \text { MON } & \text { Mixed Oxides of Nitrogen } \\ \mathrm{N}_{2} \mathrm{H}_{4} & \text { Hydrazine } \\ \mathrm{N}_{2} \mathrm{O}_{4} & \text { Nitrogen Tetroxide (also known as Di-Nitrogen Tetroxide or NTO) } \\ \text { NASA } & \text { National Aeronautics and Space Administration } \\ \text { NIOSH } & \text { National Institute of Occupational Safety and Health } \\ \text { NO } & \text { Nitrous Oxide } \\ \text { NO } & \\ \text { NSTC } & \text { Nitrogen Dioxide } \\ \text { NTO } & \text { NASA Safety Training Center } \\ \text { OMS } & \text { Nitrogen Tetroxide (also known as Di-Nitrogen Tetroxide) } \\ \text { OPF } & \text { Orbital Maneuvering System } \\ \text { ORSU } & \text { Orbiter Processing Facility (located at KSC) } \\ \text { OSHA } & \text { Oxidizer Ready Storage Unit (located at WSTF) } \\ \text { P } & \text { Occupational Safety and Health Administration } \\ \text { PEL } & \text { Pressure } \\ \text { ppm } & \text { Permissible Exposure Limit } \\ \text { psia } & \text { Parts Per Million } \\ \text { psig } & \text { Pounds Per Square Inch Absolute } \\ \text { R } & \text { Pounds Per Square Inch Gage } \\ \text { RCS } & \text { Rankine } \\ \text { REL } & \text { Reaction Control System } \\ \text { SLC } & \text { Recommended Exposure Limit } \\ \text { SPS } & \text { Space Launch Complex } \\ \text { SRB } & \text { Spacecraft Propulsion System } \\ \text { STS } & \text { Solid Rocket Booster } \\ \text { T } & \text { Space Transportation System } \\ \text { TLV } & \text { Temperature } \\ \text { TWA } & \text { Toxic Vapor Level } \\ \text { U.S.S.R. } & \text { Time Weighted Average } \\ \text { UDMH } & \text { Union of Soviet Socialist Republics } \\ \text { USAF } & \text { United States Air Force } \\ \text { VAFB } & \text { Vandenberg Air Force Base } \\ \text { Vp } & \text { Vapor Pressure } \\ \text { WSTF } & \text { White Sands Test Facility } \\ & \end{array}$




\section{Appendix B}

\section{Summary of Incidents}

\begin{tabular}{|c|c|c|c|c|c|c|c|c|c|c|c|c|c|c|c|c|c|c|c|c|c|c|c|c|c|}
\hline$\frac{\text { Incident Location }}{\text { and Description }}$ & Date & Spill & $\sum$ & $=$ & $\frac{8}{8}$ & $\frac{\Xi}{\frac{\pi}{2}}$ & & 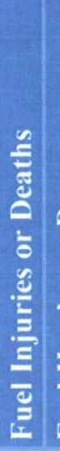 & 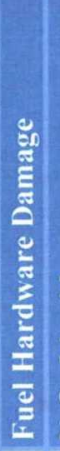 & $\frac{\pi}{2}$ & 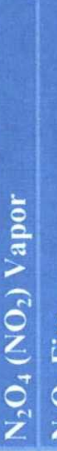 & $\frac{0}{\frac{b}{x}}$ & . & 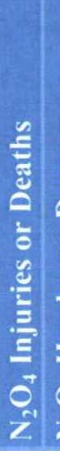 & 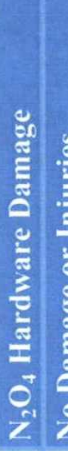 & 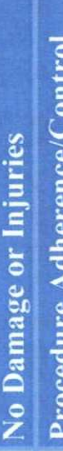 & 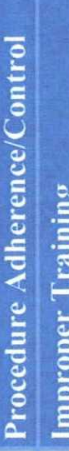 & 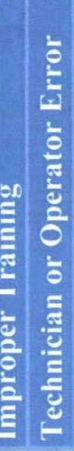 & 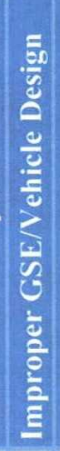 & 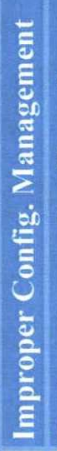 & 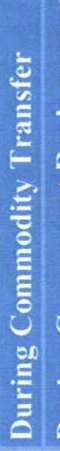 & 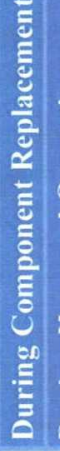 & 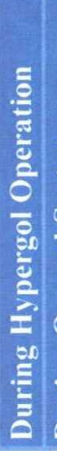 & 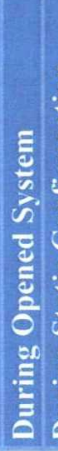 & 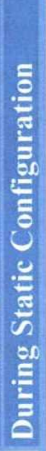 \\
\hline $\begin{array}{l}\text { LC-34 Apollo } 7 \text { SPS } \\
\mathrm{N}_{2} \mathrm{O}_{4} \text { Spill }\end{array}$ & $\begin{array}{l}\text { Sep- } \\
1968\end{array}$ & $\begin{array}{c}\sim 1 \text { to } 2 \\
\text { gal }\end{array}$ & & & & & & & & $X$ & & & & & $\mathrm{X}$ & & & & $\mathrm{X}$ & & & & & $\mathrm{X}$ & \\
\hline $\begin{array}{l}\text { Apollo-Soyuz } \\
\text { Landing Astronaut } \\
\mathrm{N}_{2} \mathrm{O}_{4} \text { Vapor } \\
\text { Exposure }\end{array}$ & $\begin{array}{l}\text { Jul- } \\
1975\end{array}$ & Vapors & & & & & & & & & $X$ & & & $X$ & & & $\mathrm{X}$ & & & & $\mathrm{X}$ & & $X$ & & \\
\hline $\begin{array}{l}\text { Enterprise APU } 1 \\
\text { Cavity Seal } \mathrm{N}_{2} \mathrm{H}_{4} \\
\text { Spill }\end{array}$ & $\begin{array}{l}\text { Jun- } \\
1977\end{array}$ & $\sim 5$ gal & & X & & & & & $X$ & & & & & & & & & & $\mathrm{X}$ & & $X$ & & $\mathrm{X}$ & & \\
\hline $\begin{array}{l}\text { Silo 533-7 Titan II } \\
\text { Silo Large Scale } \\
\mathrm{N}_{2} \mathrm{O}_{4} \text { Spill }\end{array}$ & $\begin{array}{l}\text { Aug- } \\
1978\end{array}$ & $\begin{array}{c}13,450 \\
\text { gal }\end{array}$ & & & & & & & & $X$ & & & & $\mathrm{X}$ & $X$ & & & & & $X$ & $\mathrm{X}$ & & $X$ & & \\
\hline $\begin{array}{l}\text { OPF1 } \mathrm{N}_{2} \mathrm{H}_{4} \text { Spill } \\
\text { Following APU } \\
\text { Hotfire }\end{array}$ & $\begin{array}{l}\text { Nov- } \\
1979\end{array}$ & $\sim 2$ gal & & $X$ & & & & & & & & & & & & $\mathrm{X}$ & & & $\mathrm{X}$ & & & & X & & \\
\hline $\begin{array}{l}\text { Silo } 374-7 \text { Titan II } \\
\text { Explosion Following } \\
\text { A-50 Spill }\end{array}$ & $\begin{array}{l}\text { Sep- } \\
1980\end{array}$ & $\begin{array}{c}11,140 \\
\text { gal }\end{array}$ & & & $\mathrm{X}$ & $\mathrm{X}$ & $X$ & $\mathrm{X}$ & $\mathrm{X}$ & & & & & & & & & $X$ & & & & & & & $\mathrm{X}$ \\
\hline $\begin{array}{l}\text { OPF1Wrong Flight } \\
\text { Cap } \mathrm{N}_{2} \mathrm{O}_{4} \text { Vapor } \\
\text { Release }\end{array}$ & $\begin{array}{l}\text { Jul- } \\
1981\end{array}$ & Vapors & & & & & & & & & $\mathrm{X}$ & & & $X$ & & & & X & & $\mathrm{X}$ & & $\mathrm{X}$ & $\mathrm{X}$ & & \\
\hline $\begin{array}{l}\text { Pad 39A MMH } \\
\text { Exposure Following } \\
\text { Flexhose Removal }\end{array}$ & $\begin{array}{l}\text { Jul- } \\
1981\end{array}$ & $<1 / 2 \mathrm{gal}$ & $\mathrm{X}$ & & & & & $X$ & & & & & & & & & $X$ & & $X$ & $\mathrm{X}$ & & $\mathrm{X}$ & $\mathrm{X}$ & $\mathrm{X}$ & \\
\hline $\begin{array}{l}\text { OPF1 STS-2 Right } \\
\text { Pod MMH Fire }\end{array}$ & $\begin{array}{l}\text { Fall- } \\
1981\end{array}$ & $\sim 1$ tsp & $\mathrm{X}$ & & & $\mathrm{X}$ & & & $\mathrm{X}$ & & & & & & & & & $X$ & $\mathrm{X}$ & & & & $\mathrm{X}$ & $\mathrm{X}$ & \\
\hline $\begin{array}{l}\text { Pad 39A STS-2 } \\
\mathrm{N}_{2} \mathrm{O}_{4} \text { Spill }\end{array}$ & $\begin{array}{l}\text { Sep- } \\
1981 \\
\end{array}$ & $\begin{array}{c}15 \text { to } 20 \\
\text { gal }\end{array}$ & & & & & & & & $X$ & & & & & $X$ & & & $\mathrm{X}$ & $X$ & & $\mathrm{X}$ & & $X$ & & \\
\hline $\begin{array}{l}\text { Pad 39A MMH Spill } \\
\text { and Fire During } \\
\text { Valve Replacement }\end{array}$ & $\begin{array}{l}\text { Jun- } \\
1982\end{array}$ & $\begin{array}{c}15 \text { to } 25 \\
\text { gal }\end{array}$ & $\mathrm{X}$ & & & $X$ & & & $\mathrm{X}$ & & & & & & & & $\mathrm{X}$ & & $X$ & & & $\mathrm{X}$ & $\mathrm{X}$ & $X$ & \\
\hline $\begin{array}{l}\mathrm{Pad} 39 \mathrm{~A} \mathrm{~N}_{2} \mathrm{O}_{4} \\
\text { Vapor Release from } \\
\text { Flange Gasket }\end{array}$ & $\begin{array}{l}\text { Feb- } \\
1983\end{array}$ & Vapors & & & & & & & & & $\mathrm{X}$ & & & & & $\mathrm{X}$ & & & $X$ & & & & $\mathrm{X}$ & & \\
\hline $\begin{array}{l}\text { OPF1 Forward RCS } \\
\text { Ferry Plug Removal } \\
\text { MMH Spill }\end{array}$ & $\begin{array}{l}\text { Apr- } \\
1983\end{array}$ & $\begin{array}{l}1 / 4 \text { to } 1 / 2 \\
\text { cup }\end{array}$ & $X$ & & & & & $\mathrm{X}$ & & & & & & & & & & $\mathrm{X}$ & & & & $\mathrm{X}$ & $\mathrm{X}$ & & \\
\hline $\begin{array}{l}\text { STS-9 APU } 1 \text { and } 2 \\
\text { Explosion on } \\
\text { Runway }\end{array}$ & $\begin{array}{l}\text { Dec- } \\
1983\end{array}$ & $\sim 1$ gal & & $\mathrm{X}$ & & & $\mathrm{X}$ & & $\mathrm{X}$ & & & & & & & & & & $\mathrm{X}$ & & $\mathrm{X}$ & & $\mathrm{X}$ & & \\
\hline $\begin{array}{l}\mathrm{OPF} 2 \mathrm{~N}_{2} \mathrm{O}_{4} \text { Vapor } \\
\text { Release from Loose } \\
\text { Fitting }\end{array}$ & $\begin{array}{l}\text { Feb- } \\
1984\end{array}$ & Vapors & & & & & & & & & $\mathrm{X}$ & & & & & $\mathrm{X}$ & & & & $\mathrm{X}$ & & & $\mathrm{X}$ & & \\
\hline
\end{tabular}

American Institute of Aeronautics and Astronautics 


\begin{tabular}{|c|c|c|c|c|c|c|c|c|c|c|c|c|c|c|c|c|c|c|c|c|c|c|c|c|c|c|}
\hline $\begin{array}{l}\text { Incident Location } \\
\text { and Description }\end{array}$ & Date & $\frac{\text { Soill }}{\text { Quantity }}$ & $\sum$ & $\sum^{+}$ & $\frac{8}{4}$ & $\frac{\substack{n \\
\frac{1}{3}}}{a}$ & $\frac{5}{\frac{6}{8}}$ & 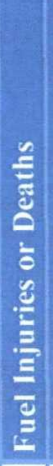 & 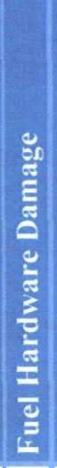 & $\frac{5}{\frac{\pi}{2}}$ & 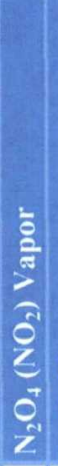 & $\frac{0}{2}$ & $\frac{5}{\frac{6}{0}}$ & 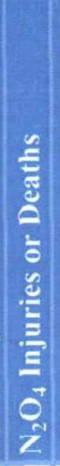 & 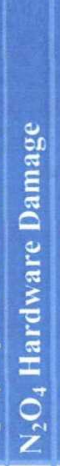 & 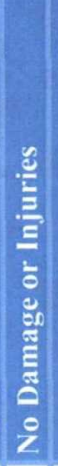 & 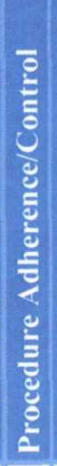 & 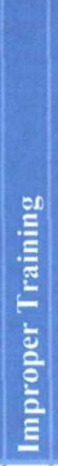 & 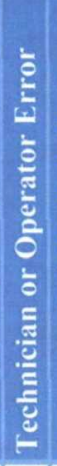 & 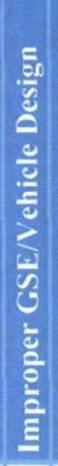 & 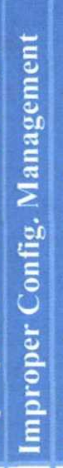 & 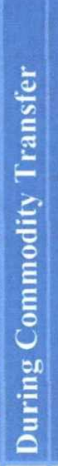 & 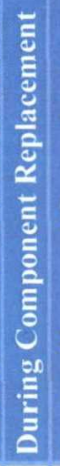 & 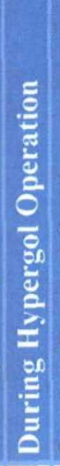 & 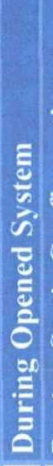 & 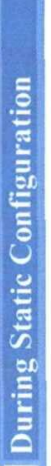 \\
\hline $\begin{array}{l}\text { CCAFS Propellant } \\
\text { Storage Area Tanker } \\
\text { MMH Fire }\end{array}$ & $\begin{array}{l}\text { May- } \\
1984\end{array}$ & $<2$ gal & $X$ & & & $\mathrm{X}$ & & $\mathrm{X}$ & $\mathrm{X}$ & & & & & & & & & $\mathrm{X}$ & & & $\mathrm{X}$ & $\mathrm{X}$ & & $\mathrm{X}$ & $X$ & \\
\hline $\begin{array}{l}\text { OPF1Liquid Trap in } \\
\text { Purge Adapter } \\
\text { Flexhose MMH Spill }\end{array}$ & $\begin{array}{l}\text { May- } \\
1985\end{array}$ & $\sim 1$ cup & $\mathrm{X}$ & & & & & & $\mathrm{X}$ & & & & & & & & $\mathrm{X}$ & & & & & $\mathrm{X}$ & $X$ & $\mathrm{X}$ & & \\
\hline $\begin{array}{l}\text { Pad 39A STS-61C } \\
\text { SRB HPU Loading } \\
\mathrm{N}_{2} \mathrm{H}_{4} \text { Spill }\end{array}$ & $\begin{array}{l}\text { Dec- } \\
1985\end{array}$ & $\sim 3$ gal & & $\mathrm{X}$ & & & & & & & & & & & & $\mathrm{X}$ & & & & $\mathrm{X}$ & & $\mathrm{X}$ & & $\mathrm{X}$ & & \\
\hline $\begin{array}{l}\text { Pad 39A Inadvertent } \\
\text { Dry Well Removal } \\
\text { MMH Spill }\end{array}$ & $\begin{array}{l}\text { Jan- } \\
1986\end{array}$ & $\sim 100$ gal & $\mathrm{X}$ & & & & & $\mathrm{X}$ & $\mathrm{X}$ & & & & & & & & & $\mathrm{X}$ & & $\mathrm{X}$ & & & $\mathrm{X}$ & $\mathrm{X}$ & & \\
\hline $\begin{array}{l}\text { Pad 39A Oxidizer } \\
\text { Relief Valve } \\
\text { Replacement } \mathrm{N}_{2} \mathrm{O}_{4} \\
\text { Vapor Release }\end{array}$ & $\begin{array}{c}\text { Jul- } \\
1986\end{array}$ & Vapors & & & & & & & & & $\mathrm{X}$ & & & $\mathrm{X}$ & & & & & $\mathrm{X}$ & $\mathrm{X}$ & & & $\mathrm{X}$ & $\mathrm{X}$ & $\mathrm{X}$ & \\
\hline $\begin{array}{l}\text { OPF2Trench } \mathrm{N}_{2} \mathrm{H}_{4} \\
\text { Spill and Fire }\end{array}$ & $\begin{array}{l}\text { Sep- } \\
1986\end{array}$ & $<1 / 2$ gal & & $\mathrm{X}$ & & $\mathrm{X}$ & & & & & & & & & & $\mathrm{X}$ & & & & & $\mathrm{X}$ & $\mathrm{X}$ & & $\mathrm{X}$ & & \\
\hline $\begin{array}{l}\text { Pad } 39 \mathrm{~B} \mathrm{~N}_{2} \mathrm{O}_{4} \text { and } \\
\text { Insulation Adhesive } \\
\text { Small Fire }\end{array}$ & $\begin{array}{l}\text { Jun- } \\
1988\end{array}$ & $\sim 2$ tbsp & & & & & & & & $\mathrm{X}$ & & $\mathrm{X}$ & & & $\mathrm{X}$ & & & & $\mathrm{X}$ & & & $\mathrm{X}$ & & $\mathrm{X}$ & & \\
\hline $\begin{array}{l}\text { Pad 39B STS-26R } \\
\mathrm{N}_{2} \mathrm{O}_{4} \text { Tubing Leak } \\
\text { on Vehicle }\end{array}$ & $\begin{array}{l}\text { Jul- } \\
1988\end{array}$ & Vapors & & & & & & & & & $\mathrm{X}$ & & & & & $\mathrm{X}$ & & $\mathrm{X}$ & $\mathrm{X}$ & & & $\mathrm{X}$ & & $\mathrm{X}$ & & \\
\hline $\begin{array}{l}\text { WSTF Fuel Waste } \\
\text { Flash Fire }\end{array}$ & $\begin{array}{l}\text { Feb- } \\
1990\end{array}$ & $\begin{array}{l}\text { None } \\
\text { spilled }\end{array}$ & $\mathrm{X}$ & & $\mathrm{X}$ & & & & & & & & & & & & & $\mathrm{X}$ & & & $\mathrm{X}$ & & & $\mathrm{X}$ & & \\
\hline $\begin{array}{l}\text { WSTF Aspiration of } \\
\mathrm{N}_{2} \mathrm{O}_{4} \text { into Fuel Vent } \\
\text { System }\end{array}$ & $\begin{array}{l}\text { Mar- } \\
1990\end{array}$ & $\sim 2$ tbsp & & & & & & & & X & & $\mathrm{X}$ & & & $\mathrm{X}$ & & & & & & $\mathrm{X}$ & $\mathrm{X}$ & $X$ & $\mathrm{X}$ & & \\
\hline $\begin{array}{l}\text { HMF Screens Test } \\
\text { Drum MMH Spill }\end{array}$ & $\begin{array}{l}\text { Dec- } \\
1990\end{array}$ & $\begin{array}{c}\sim 1 \text { to } 2 \\
\text { gal }\end{array}$ & $\mathrm{X}$ & & & & & & & & & & & & & $\mathrm{X}$ & & & $\mathrm{X}$ & $X$ & & $\mathrm{X}$ & & $\mathrm{X}$ & & \\
\hline $\begin{array}{l}\text { OPF3 STS-42 Ferry } \\
\text { Plug Removal MMH } \\
\text { Spill }\end{array}$ & $\begin{array}{l}\text { Feb- } \\
1992\end{array}$ & $\begin{array}{c}\sim 1 / 4 \text { to } 3 / 4 \\
\text { cup }\end{array}$ & $\mathrm{X}$ & & & & & & & & & & & & & $\mathrm{X}$ & & & & $\mathrm{X}$ & & & $X$ & $\mathrm{X}$ & & \\
\hline $\begin{array}{l}\text { WSTF Incorrect } \\
\text { Flight Cap } \mathrm{N}_{2} \mathrm{O}_{4} \\
\text { Exposure }\end{array}$ & $\begin{array}{l}\text { Nov- } \\
1992\end{array}$ & $\sim 1$ cup & & & & & & & & $\mathrm{X}$ & & & & $\mathrm{X}$ & & & & $\mathrm{X}$ & $\mathrm{X}$ & $\mathrm{X}$ & & & $\mathrm{X}$ & $\mathrm{X}$ & & \\
\hline $\begin{array}{l}\text { JSC Thermo- } \\
\text { Chemical Test Area } \\
\mathrm{N}_{2} \mathrm{O}_{4} \text { Vapor Release }\end{array}$ & $\begin{array}{l}\text { Apr- } \\
1994\end{array}$ & $\begin{array}{l}\sim 16 \text { to } \\
20 \text { gal }\end{array}$ & & & & & & & & $\mathrm{X}$ & $\mathrm{X}$ & & & $\mathrm{X}$ & & & & $\mathrm{X}$ & $\mathrm{X}$ & $\mathrm{X}$ & $\mathrm{X}$ & $X$ & & $\mathrm{X}$ & & \\
\hline $\begin{array}{l}\mathrm{SLC}-41 \text { Titan IV A } \\
\mathrm{K}-9 \mathrm{~N}_{2} \mathrm{O}_{4} \text { Spill }\end{array}$ & $\begin{array}{l}\text { Aug- } \\
1994 \\
\end{array}$ & $\begin{array}{l}350 \text { to } \\
400 \mathrm{gal}\end{array}$ & & & & & & & & $\mathrm{X}$ & & & & & $\mathrm{X}$ & & $\mathrm{X}$ & & & $\mathrm{X}$ & & & & & & X \\
\hline $\begin{array}{l}\text { OPF1 STS-69 Left } \\
\text { Pod MMH Fire }\end{array}$ & $\begin{array}{l}\text { Dec- } \\
1994\end{array}$ & $<1$ cup & $\mathrm{X}$ & & & $\mathrm{X}$ & & & & & & & & & & X & & $\mathrm{X}$ & $\mathrm{X}$ & & & & $\mathrm{X}$ & $\mathrm{X}$ & $\mathrm{X}$ & \\
\hline
\end{tabular}

9

American Institute of Aeronautics and Astronautics 


\begin{tabular}{|c|c|c|c|c|c|c|c|c|c|c|c|c|c|c|c|c|c|c|c|c|c|c|}
\hline $\begin{array}{l}\text { Incident Location } \\
\text { and Description }\end{array}$ & Date & Quantity & E & $=$ & $\frac{8}{4}$ & 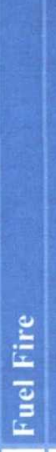 & & 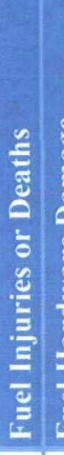 & 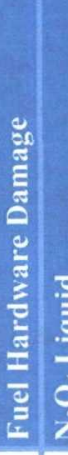 & 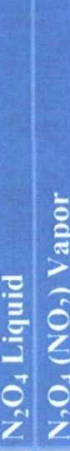 & 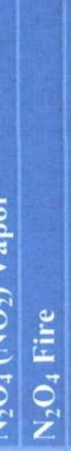 & 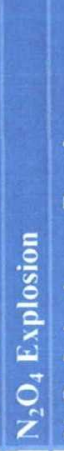 & 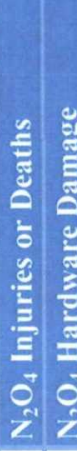 & 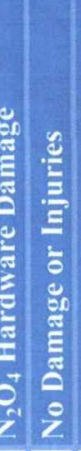 & 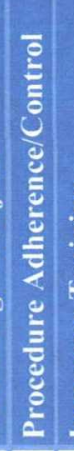 & 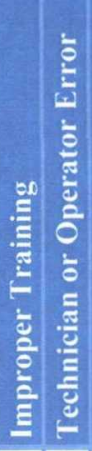 & 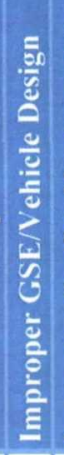 & 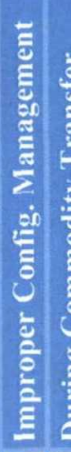 & 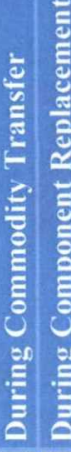 & 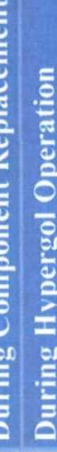 & & 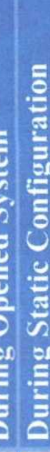 \\
\hline $\begin{array}{l}\text { OPF1 STS-69 Right } \\
\text { Pod MMH Fire }\end{array}$ & $\begin{array}{l}\text { May- } \\
1995\end{array}$ & $<1$ cup & $\mathrm{X}$ & & & $\mathrm{x}$ & & & $\mathrm{X}$ & & & & & & & $x$ & & & X & $x$ & $x$ & \\
\hline $\begin{array}{l}\text { WSTF ORSU Open } \\
\text { Manual Valve } \mathrm{N}_{2} \mathrm{O}_{4} \\
\text { Spill }\end{array}$ & $\begin{array}{l}\text { Mar- } \\
1996\end{array}$ & $\sim 90 \mathrm{gal}$ & & & & & & & & $\mathrm{X}$ & & & & $\mathrm{X}$ & & & $\mathrm{X}$ & $\mathrm{X}$ & & $\mathrm{X}$ & & \\
\hline $\begin{array}{l}\text { OPF2 GSE MMH } \\
\text { Spill }\end{array}$ & $\begin{array}{l}\text { Feb- } \\
1997\end{array}$ & $\sim 1$ pint & $\mathrm{X}$ & & & & & $\mathrm{X}$ & & & & & & & & & $\mathrm{X}$ & & X & \begin{tabular}{l|l}
$x$ & $X$
\end{tabular} & $x$ & \\
\hline $\begin{array}{l}\text { HMF Sample Valve } \\
\text { MMH Spill }\end{array}$ & $\begin{array}{l}\text { Mar- } \\
1997\end{array}$ & $\sim 3 / 4$ cup & $\mathrm{X}$ & & & & & $\mathrm{X}$ & & & & & & & & $\mathrm{X}$ & & & & X & $x$ & \\
\hline $\begin{array}{l}\text { SLC-4E Titan IV K- } \\
18 \mathrm{~N}_{2} \mathrm{O}_{4} \text { Spill }\end{array}$ & $\begin{array}{c}\text { Jul- } \\
1997\end{array}$ & $\sim 244$ gal & & & & & & & & $\mathrm{X}$ & & & X & $\mathrm{X}$ & & & $\mathrm{X}$ & & & X & & \\
\hline $\begin{array}{l}\text { Pad 39B Slope } \mathrm{N}_{2} \mathrm{O}_{4} \\
\text { Spill }\end{array}$ & $\begin{array}{l}\text { Nov- } \\
1997 \\
\end{array}$ & $\begin{array}{c}25 \text { to } 50 \\
\text { gal }\end{array}$ & & & & & & & & $\mathrm{X}$ & $\mathrm{x}$ & & X & $x$ & & & & \begin{tabular}{l|l}
$x$ & $y$
\end{tabular} & $\mathrm{X}$ & X & & \\
\hline $\begin{array}{l}\text { OPF3 STS-109 APU } \\
\mathrm{N}_{2} \mathrm{H}_{4} \text { Spill }\end{array}$ & $\begin{array}{l}\text { Aug- } \\
1999 \\
\end{array}$ & $<5$ tbsp & & $\mathrm{X}$ & & & & & $\mathrm{X}$ & & & & & & & $\mathrm{X}$ & $\mathrm{X}$ & & & X & $x$ & $\mathrm{X}$ \\
\hline $\begin{array}{l}\text { WSTF Pathfinder } \\
\text { Axial Engine Valve } \\
\text { Failure }\end{array}$ & $\begin{array}{l}\text { Aug- } \\
2000\end{array}$ & $\begin{array}{l}\sim 1 \text { to } 2 \\
\text { gal }\end{array}$ & & & & & & & & $\mathrm{X}$ & & $x$ & X & $x$ & $\mathrm{X}$ & & & & $\mathrm{X}$ & $x$ & & \\
\hline $\begin{array}{l}\text { WSTF Pathfinder } \\
\text { Small MMH Fire }\end{array}$ & $\begin{array}{l}\text { Aug- } \\
2000\end{array}$ & $\sim 1$ cup & $\mathrm{X}$ & & & $\mathrm{X}$ & & & $\mathrm{X}$ & & & & & & & $\mathrm{X}$ & & & & X & & \\
\hline $\begin{array}{l}\text { WSTF Pressure } \\
\text { Transducer } \\
\text { Explosion }\end{array}$ & $\begin{array}{l}\text { Mar- } \\
2003\end{array}$ & $\begin{array}{c}\sim 3 \\
\text { quarts }\end{array}$ & & & & & & & & $\mathrm{X}$ & & $\mathrm{X}$ & X & $x$ & & & $\mathrm{X}$ & & $\mathrm{X}$ & X & $x$ & \\
\hline $\begin{array}{l}\text { LC-40 Titan IV } \\
\mathrm{N}_{2} \mathrm{O}_{4} \text { Pump } \\
\text { Explosion }\end{array}$ & $\begin{array}{l}\text { Aug- } \\
2003\end{array}$ & $\sim 40 \mathrm{gal}$ & & & & & & & & $\mathrm{X}$ & & $\mathrm{x}$ & \begin{tabular}{l|l}
$X$ & $X$
\end{tabular} & $\mathrm{x}$ & & $\mathrm{X}$ & $X$ & & $\mathrm{X}$ & X & $\mathrm{x}$ & \\
\hline $\begin{array}{l}\text { HMF STS-115 Right } \\
\text { Pod } \mathrm{N}_{2} \mathrm{O}_{4} \text { Spill }\end{array}$ & $\begin{array}{l}\text { Jun- } \\
2004\end{array}$ & $\sim 1.4 \mathrm{gal}$ & & & & & & & & $\mathrm{X}$ & & & $\mathrm{X}$ & & $\mathrm{X}$ & $\mathrm{X}$ & & & X & $\mathrm{x}$ & $\mathrm{X}$ & \\
\hline $\begin{array}{l}\text { WSTF } \mathrm{N}_{2} \mathrm{H}_{4} \text { Spill } \\
\text { Following Manual } \\
\text { Valve Failure }\end{array}$ & $\begin{array}{l}\text { Sep- } \\
2005\end{array}$ & $\sim 74 \mathrm{gal}$ & & $X$ & & & & & $\mathrm{X}$ & & & & & & & & $\mathrm{X}$ & $\mathrm{X}$ & & & & $X$ \\
\hline $\begin{array}{l}\text { HMF STS- } 121 \\
\text { Forward RCS } \mathrm{N}_{2} \mathrm{O}_{4} \\
\text { Spill }\end{array}$ & $\begin{array}{l}\text { Jan- } \\
2006\end{array}$ & $\sim 2.9 \mathrm{gal}$ & & & & & & & & X & & & $\mathrm{X}$ & & & $\mathrm{X}$ & & & $X$ & $x>$ & \begin{tabular}{l|l}
$X$ \\
$X$
\end{tabular} & $\mathrm{X}$ \\
\hline
\end{tabular}




\section{Acknowledgments}

B. Nufer thanks the following people for their very generous help and support in studying hypergolic related spills and fires: Thomas Draus, David Shinn, Shaun Butts, Ronald Rehagen, Walter Schmitz, Andrew Maffe, Thomas Dempsey, John "Jack" Jamba, Kurt Rathgeber, Conrad Perez, Manfred Heinrich, Charles Pierce, Frank Golan, Gregory Kamp, Robert Dougert, Dallas McCarter, Jeffrey Skaja, Larry Ross, Michael Slusher, Mark Raysich, Milivoje (Mike) Stefanovic, Donald Clarkson, Chuck Davis, Joe Nieberding, Chad Summers, Jason Clark, Dr. Jeffrey Myers, David Koci, George (Frank) Norris, Jean Hill, Benjamin Greene, and Jennifer Nufer

\section{References}

1 "Fire, Explosion, Compatibility, and Safety Hazards of Nitrogen Tetroxide." American Institute of Aeronautics and Astronautics Special Project Report. AIAA SP-086-2001. 2001.

${ }^{2}$ Myers, Jeffrey, M.D. "RE: Hyper Spills \& Accidents Lessons Learned Report - Toxicology of $\mathrm{NO}_{2}$ Inhalation." E-mail to Jeffrey Myers and Frank Golan. August 72008.

${ }^{3}$ Hall, George F., Raymond Lake, John H. Storm, and Ross J. Utt. "Fire Protection Research and Development Requirements Analysis for USAF Space Systems and Ground Support Facilities Volume I - Fire Protection Operational Requirements Analysis." Flight Dynamics Directorate Wright Laboratory Air Force Materiel Command, Tyndall Air Force Base, FL. WL-TR-96-3010. April, 1995.

${ }^{4}$ Rathgeber, Kurt A., Bruce Havenor, and Steven D. Hornung Ph.D. "Hypergol Systems: Design, Buildup, and Operation." NSTC Course 055. January 6, 2006.

${ }^{5}$ United States. Dept. of Health, Education, and Welfare (DHEW), Public Health Service, Center for Disease Control, National Institute for Occupational Safety and Health (NIOSH). "Occupational Exposure to Hydrazines." NIOSH Criteria for a Recommended Standard. U.S. DHEW (NIOSH) Publication No. 78-172. June 1978.

${ }^{6}$ Benz, F. J. and M. D. Pedley. "A Comparison of the Explosion Hazards of Hydrazine and Methylhydrazine in Aerospace Environments." CPIA-PUB-455, Volume 1, pp 477-488. 1986.

7 "Fire, Explosion, Compatibility, and Safety Hazards of Hypergols - Monomethylhydrazine." American Institute of Aeronautics and Astronautics Special Project Report. AIAA SP-085-1999. 1999.

8 "Fire, Explosion, Compatibility, and Safety Hazards of Hypergols - Hydrazine. American Institute of Aeronautics and Astronautics Special Project Report. AIAA SP-084-1999. 1999.

${ }^{9}$ United States. National Aeronautics and Space Administration. "NASA Occupational Health Program Procedures." NPR 1800.1 Revision C. Oct. 6, 2009: 